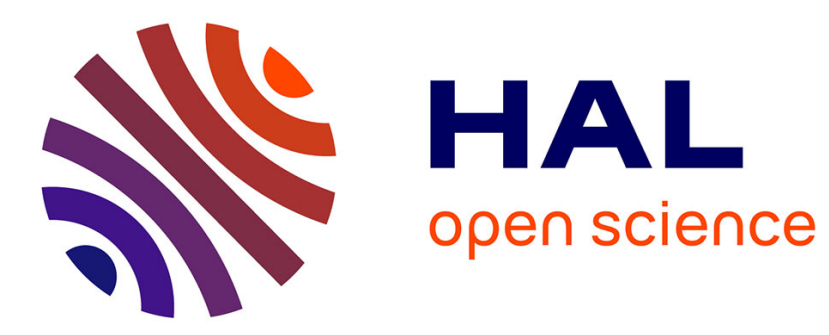

\title{
Agricultural water poverty index and sustainability Forouzani, Karami
}

\section{To cite this version:}

Forouzani, Karami. Agricultural water poverty index and sustainability. Agronomy for Sustainable Development, 2011, 31 (2), pp.415-431. 10.1051/agro/2010026 . hal-00930457

\section{HAL Id: hal-00930457 https://hal.science/hal-00930457}

Submitted on 1 Jan 2011

HAL is a multi-disciplinary open access archive for the deposit and dissemination of scientific research documents, whether they are published or not. The documents may come from teaching and research institutions in France or abroad, or from public or private research centers.
L'archive ouverte pluridisciplinaire HAL, est destinée au dépôt et à la diffusion de documents scientifiques de niveau recherche, publiés ou non, émanant des établissements d'enseignement et de recherche français ou étrangers, des laboratoires publics ou privés. 
Agron. Sustain. Dev. (2011) 31:415-432

(C) INRA, EDP Sciences, 2010

DOI: 10.1051 /agro/2010026

\title{
Review article
}

\section{Agricultural water poverty index and sustainability}

\author{
Masoumeh ForoUZANI, Ezatollah KARAMI* \\ Department of Agricultural Extension, College of Agriculture, Shiraz University, Shiraz 71441-65186, Iran
}

(Accepted 12 April 2010) (Published online: 4 October 2010)

\begin{abstract}
Water resources are declining at an alarming rate in the world. The use of water resources for agricultural production has contributed to the rapid decline in quantity and degradation of water quality. Though sustainable agriculture must be economically viable, ecologically sound and socially responsible, water scarcity has challenged the sustainability of agriculture, especially in arid and semi-arid regions. There is a relative consensus among professionals that the increasing water scarcity through excessive use of water and mismanagement of the available water resources are major concerns for agricultural sustainability. Agricultural sustainability is assessed using various indicators, but the contribution of the water factor in those indicators is limited. Therefore, we review the role of sustainable water management in achieving agricultural sustainability. We propose an agricultural water poverty index (AWPI) as an instrument to provide a holistic picture of vital issues for sustainable water management. We also distill key components of the agricultural water poverty index and discuss its applications. The agricultural water poverty index can be used to assess the agricultural water poverty among farmers and regions and to provide guidelines for sustainable water management. This article uses the case of Iran to illustrate the application of the agricultural water poverty index in analyzing agricultural water poverty and providing recommendations for sustainable water management.
\end{abstract}

sustainable agriculture / water management sustainability / agricultural water poverty / Iran

\section{Contents}

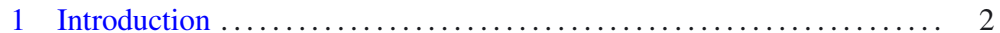

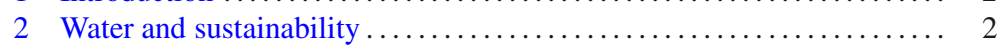

2.1 Water and ecological/environmental dimension $\ldots \ldots \ldots \ldots \ldots .2$

2.2 Water and economic dimension $\ldots \ldots \ldots \ldots \ldots \ldots \ldots \ldots \ldots \ldots$

2.3 Water and social dimension $\ldots \ldots \ldots \ldots \ldots \ldots \ldots \ldots \ldots \ldots \ldots . \ldots \ldots \ldots$

3 Characterizing indices in water assessment .................. 4

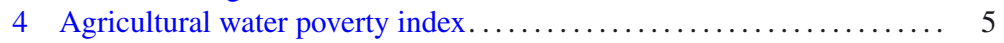

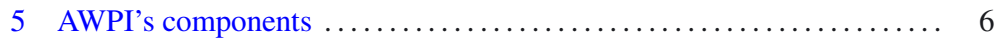

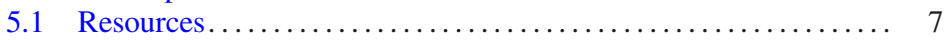

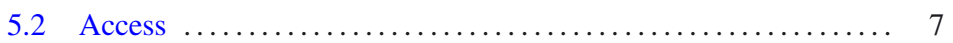

5.2.1 Farmers' access to water $\ldots \ldots \ldots \ldots \ldots \ldots \ldots \ldots \ldots \ldots$

5.2.2 Potential and quality of land $\ldots \ldots \ldots \ldots \ldots \ldots \ldots \ldots$

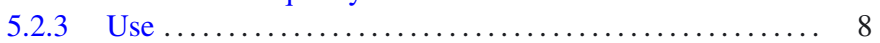

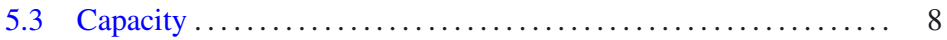

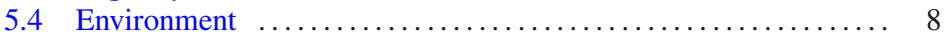

6 Potential applications (functions) of the AWPI $\ldots \ldots \ldots \ldots \ldots \ldots \ldots$

7 Water and sustainability of agriculture: the case of iran $\ldots \ldots \ldots \ldots .9$

8 A historical perspective of water challenges in agriculture ......... 10

8.1 Water Conservation Era (up to land reform of 1961)......... 10

\footnotetext{
*Corresponding author: Forouzani@ shirazu.ac.ir
} 
8.2 Water Exploitation Era (from land reform up to self-sufficiency in wheat production of 2004) . . . . . . . . . . . 10

8.3 Water Crisis Era (after self-sufficiency in wheat production) . . . 11

9 Agricultural water poverty analysis of Iran's agriculture . . . . . . . . 12

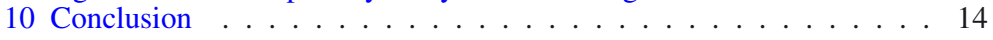

\section{INTRODUCTION}

Water has become an increasingly important determinant of agricultural sustainability, especially in arid and semi-arid areas of the world. Demand for water is increasing worldwide. Increased water scarcity implies that options for water resource development are becoming limited (Yokwe, 2009). The agriculture sector is known as the most dominant user of water in the world. Increased agricultural productivity is highly dependent on the status of the natural resource base and social security is also heavily dependent on how these resources are used (Abalu and Hassan, 1998). However, the growing water scarcity and the misuse and management of the available water resources are major threats to sustainable development for the agricultural sector (Hamdy et al., 2003). Hence, the dominant water resources management challenge over the coming generations is how to secure water to cover the food demands of a rapidly expanding world population (Rockström et al., 2004).

The definition of sustainable agriculture as "the ability of farming systems to continue into the future" implies that sustainable agriculture must preserve the ability to farm and produce food into the foreseeable future, without reducing the options available for following generations (Gafsi et al., 2006). However, lack of sufficient water in some parts of the world has already impaired sustainability, decreased opportunities and is declining rural society.

A sustainable agriculture must be economically viable, ecologically sound and socially responsible (Safley, 1998; Rasul and Thapa, 2004). 'Ecological soundness' refers to the preservation and improvement of the natural environment. 'Economic viability' refers to maintenance of yields and productivity of crops and livestock, and 'social acceptability' refers to self-reliance, equality and improved quality of life (Rasul and Thapa, 2004). In other words, sustainability cannot be compressed into a single dimension and it seems sensible to monitor a range of sustainability indicators (De Koeijer et al., 2002). The development of indicators can be an effective tool in the operationalization of agricultural sustainability (Rigby et al., 2001).

The goal of this study is to illustrate the need for an agricultural water poverty index (AWPI) to assist in understanding and achieving agricultural sustainability using the case of Iran. In light of this goal, this article explores the concept of sustainable water management. It addresses the crucial role of water in achieving agricultural sustainability. It proposes an AWPI and examines its application in understanding and achieving sustainability. Finally, dimensions of the agricultural water poverty framework will be used in a historical review of water issues in Iran's agriculture in order to point out the challenges of sustainability.

\section{WATER AND SUSTAINABILITY}

Although the importance of sustainability in agriculture is no longer in question (Gafsi et al., 2006), it is an opportune time to change the main question of sustainable agriculture, namely "can agriculture be practiced in a manner that both satisfies demands for food and fiber and is environmentally responsible and socially acceptable?" (Safley, 1998) into "can agricultural water be managed in a manner that satisfies both demands for food and fiber and is environmentally sound and socially responsible?" Therefore, agricultural water sustainability is, to some extent, a new notion that requires to be translated into practical management methods, and there is a clear need to operationalize water sustainability aspects using appropriate systems of assessment. It is realized that the sustainability of an agricultural system springs from greater economic returns, from better achievement of social welfare objectives or from more proper protection of ecological/environmental systems. But lack of water has unfavorable effects on access to sustain farming systems. A large number of sustainability indicators have already been proposed in the existing literature relevant to agriculture. The value of a sustainability indicator springs from its potential to improve decision-making, and so it is best thought of as a source of information (Pannell and Glenn, 2000). However, a precise examination and analysis of agricultural sustainability indicators reveals that water, as a main element in agriculture, has no or very little contribution to the indicators developed by researchers (i.e. Rigby et al., 2001; Golusin and Munitlak Ivanovic, 2009; Hanley et al., 1999; Gómez-Limón and Riesgo, 2009; Nader et al., 2008; Aistars, 1999), whereas others (i.e. Rasul and Thapa, 2004; Wilson and Tisdell, 2001) have noted that a major requirement for sustainable agriculture is sustainable management of water resources. The sustainable management of water resources, therefore, implies not only indefinite continuation of physically and biologically stable systems, but also concern for the other dimensions of sustainable development, such as the economic efficiency of water use, the equitable distribution of the costs and benefits of water resource development and participatory approaches to the policy-making and decision-making process (Ioris et al., 2008).

Water has a major role to play in agricultural sustainability; therefore, in the next section a brief description of the impact of water on dimensions of agricultural sustainability is presented.

\subsection{Water and ecological/environmental dimension}

From an ecological point of view, ecological health is more important than the productivity of a system, but farm 
productivity, in many cases, has resulted in the reduced longterm health of systems in recent years (Stephen, 2004), because natural resources are not being utilized in a sustainable manner. In this regard, intensification of crops, coupled with excess use of external inputs such as fertilizers, pesticides and herbicides have led to serious ecological problems in nature (Rasul and Thapa, 2004). They have contributed to the rapid decline in quality of natural resources, especially contamination of surface and groundwaters, and decline in soil productivity as well. Crop intensification has also been blamed for climate changes such as variations in temperature and precipitation patterns that cause a decrease in the quantity of water resources through decreasing precipitation (Thomas, 2008). With the prospect of larger variations brought about by climate change, farmers are faced with even greater uncertainties about water supplies for crops and agricultural practices are driving environmental change (Bucks, 1991; Maneta et al., 2009). So, it seems that water has a significant role in sustaining agriculture with regard to the ecological domain. Thus, lack of vegetation cover in farms as a result of water shortage is an important indicator for measuring the environmental dimension of sustainability in agriculture (Gómez-Limón and Riesgo, 2009).

\subsection{Water and economic dimension}

The concerns about water in agriculture have included loss of economic viability of agriculture due to its influence, directly or indirectly, on employment and the income distribution in this sector. One of the most obvious effects of water scarcity in the agricultural sector is the declining land productivity and growing farm costs (mainly due to use of excessive energy, e.g. machinery, fuel, etc. to exploit groundwater resources).

Farmers are experienced managers of their business environment. They can perceive the environmental and climate changes that endanger their economic viability. Many of them are looking for profitable paths that remedy their losses and increase economic efficiency. So, farmers' immediate concern for agricultural activity is how to increase their income through increased crop yield and decrease the risk of crop failure. Because under water scarcity situations, they naturally are forced to decrease their cultivation areas, and consequently their income will be diminished.

The other issue that should be illustrated is that from the farmers' point of view usually the financial benefits from current resources are considered more important and more motivational than other impacts caused by those resources. Since the main purpose of farmers is maximization of the overall economic return from their farm, when they are faced with declining productivity as a result of water shortage, their net profit is less than the expected value of economic benefit from agriculture and consequently, they embark upon alternative livelihood strategies or in some cases they are hesitant to continue to farm into the future.

In general, when farmers face water crisis, there is no option for them that can economically address the sustainability of their agricultural system. Indeed, this has an unfavorable influence on food security and the economic/political stability of the society in the form of GDP as well.

\subsection{Water and social dimension}

The most important cross-cutting Millennium Development Goals are poverty alleviation and securing environmental sustainability, both of which, in developing countries, are strongly linked to agricultural development (Hengsdijk et al., 2007). In the UN millennium development goals (MDGs), for the water sector, a number of goals and targets are relevant and demanding (UNESCO, 2003, cited in: Sullivan et al., 2006a, p. 412). For example, Goal No. 7, to "ensure environmental sustainability", is of particular relevance, and Goal No. 1, to "eradicate extreme poverty and hunger", is also significant because the vast proportion of water used by humans is for agriculture (Sullivan et al., 2006a).

Hence, lack of access to agricultural water decreases agriculture productivity, and consequently, increases poverty in rural regions. Agriculture seems to be a primary source of provision and distribution of rural income (Gómez-Limón and Riesgo, 2009), and poverty of the rural society may be the main reason behind the low or lack of access to water for agriculture. This closed loop connection between the welfare of a rural society and access to water leads to more weaknesses and poverty in that society. Hence, one side of this issue suggests when addressing the problem of poverty, at the society level, water allocation is highly relevant as it is impossible to escape extreme poverty without adequate access to water (Sullivan et al., 2006a), while the other side relates it with quality of life at the individual level.

Typically, measurement of quality of life overall or within a specific life domain (at any level of analysis) has been done through either subjective or objective indicators. Subjective indicators are mostly based on psychological responses, such as life satisfaction and job satisfaction among others; and objective indicators are measured based on frequency or physical quantity, such as personal income, standard of living, etc. (Malkina-Pykh and Pykh, 2008). As farmers perceive negative changes such as lack of water for irrigation practices, satisfaction with the area as a place to farm is also expected to decline. As this satisfaction decreases, the expectation of continuing the farming operation is also likely to decline. The extent to which farmers enjoy intrinsic rewards from farming should bear directly on their expectation to continue farming (Zollinger and Krannich, 2002). Ennis-McMillan (2006 cited in: Wutich and Ragsdale, 2008, p. 2116) documented a phenomenon called "suffering from water" in which members of a Mexican community experienced emotional responses such as frustration, anguish, bother, worry and anger over water shortages. Consequently, in the water scarcity situations farmers' quality of life either subjectively or objectively will decrease. So, agricultural water concerns directly or indirectly have also been accompanied by social concerns such as food quality, human health impairment (Safley, 1998), the steady migration 
from rural to urban areas, unemployment in rural areas, increased crime rate in society, decreased social equality, etc.

The current increased demand on water supply is due to population and economic growth, industrialization, and urbanization, and there is a pressing need to address both equity in water allocation (social justice) and water-use efficiency (environmental integrity) (Yokwe, 2009). Not surprisingly, an improvement in water usage and paying attention to environmental integrity results in improvement in the quality of life (Nijkamp and Vreeker, 2000). Currently there is a need for a proper tool, which would enable aggregating the main aspects of agricultural water into an index. In the next section, some determinate indices in water assessment have been distilled and an Agricultural Water Poverty Index as a new index along with its implications in agriculture is discussed.

\section{CHARACTERIZING INDICES IN WATER ASSESSMENT}

According to Ohlsson (2000), a number of water stress and vulnerability indices were constructed with the aim of estimating future water vulnerability such as: (a) use-to-resource ratio (a measurement of the total pressure on water resources and aquatic systems); (b) coefficient of variation of precipitation (a measurement of hydrological fluctuations); (c) storage-to-flow ratio (an indicator of the infrastructural capacity to ameliorate fluctuations in supply); and (d) import dependence (an indicator of the reliance on virtual water).

Since the 1970s, the need to assess water resource availability has been recognized. A number of attempts have been made to estimate water supplies, both globally and regionally (Sullivan, 2002). One of the first studies which highlighted the importance of linking the physical assessments of water to the needs of human populations was conducted by Falkenmark and Lindh (1974, cited in: Sullivan, 2002, p. 1200). Indeed, Falkenmark, Lundqvist and Widstrand (1989, cited in: Heidecke, 2006, p. 11) describe water stress as water available per capita and year, differentiating four categories:

1. availability $>1700 \mathrm{~m}^{3} /$ capita/year means water shortage occurs only irregularly or locally;

2. availability $<1700 \mathrm{~m}^{3} /$ capita/year means water stress appears regularly;

3. availability $<1000 \mathrm{~m}^{3} /$ capita/year means water scarcity is a limitation to economic development and human health and well-being;

4. availability $<500 \mathrm{~m}^{3} /$ capita/year means water availability is a major constraint to life.

The search for more representative indicators and a more holistic approach led to linking the physical assessments of water with relevant social factors, taking into account factors associated with the Human Development Index (Lawrence et al., 2002). In this manner, Leif Ohlsson (2000) assessed "available renewable water" as the physical measurement of his model and he linked it to "adaptive capacity" through the use of the UNDP Human Development Index to create the Social Water Stress/Scarcity Index. He developed the
"Falkenmark" or "water stress index" into the social water scarcity index (SWSI) to reflect hydrological water scarcity in relationship to the social conditions of a country by dividing the HWSI (hydrological water stress index) by the HDI (Heidecke, 2006).

$$
\text { SWSI }=\frac{\text { HWSI }}{\frac{\text { HDI }}{2}} \text {. }
$$

The resulting values are then classified, illustrating diverse stages of water availability: (a) 5 means relative sufficiency; (b) 6-10 means stress; (c) 11-20 means scarcity; and (d) $>20$ means beyond the barrier.

Ohlsson (2000) believes that this index would not only serve to highlight the importance of a society's social adaptive capacity facing the challenges of water scarcity, but also gets rid of some annoying anomalies present in that first-generation index. He adds that using this index can change initial countries' ranking (determined through the HWSI), so that some countries such as Niger, Afghanistan, Burkina Faso, Eritrea and Nigeria will move from "relative sufficiency" to the "water stress" category.

While demonstrating some variation, these examples of water assessments all indicate the urgency of the need to develop more equitable and sustainable approaches to water management. The global water insecurity is considered as a phenomenon that arises from inequitable distribution of water rights, economic resources and resource availability (Wutich and Ragsdale, 2008). Thus, in order to move towards a more comprehensive and accurate assessment of the situation a monitoring tool that looks at water availability and access in a more holistic way is needed, a tool which overcomes or minimizes some of the weaknesses of other indicators (Sullivan et al., 2006a). According to Sullivan (2002), this is a significant step forward toward the development of a Water Poverty Index. Whereas assisting with the challenges of local water management is one of the main objectives in the development of the Water Poverty Index (WPI, Sullivan et al., 2006a), it was designed to contribute to the global effort to tackle water problems, particularly as they relate to the poor (Sullivan, 2002; Sullivan et al., 2003). The WPI was also identified as a possible indicator for monitoring progress toward increasing the number of people with access to water and indicate if the progress actually contributes to the wider water-related context, namely the Millennium Development Goals of reduced hunger, improved food security and better health (Heidecke, 2006). It was intended to "produce an integrated assessment of water stress and scarcity, linking physical estimates of water availability with socioeconomic variables that reflect poverty" as well (Komnenic et al., 2009). According to its developers, Sullivan and her colleague, the WPI is an interdisciplinary management tool within a structural framework that is capable of identifying communities where poverty, social deprivation, health, environmental integrity and water availability become more explicit, enabling policy-makers to identify appropriate mechanisms to deal with the causes of these problems (Sullivan, 2002; Sullivan and Meigh, 2003; Mlote et al., 2002). 
Table I. Comparison of devised indices in water assessment.

\begin{tabular}{|c|c|c|c|}
\hline Trait & First generation & Second generation & Third generation \\
\hline Index & $\begin{array}{l}\text { Hydrological Water Stress Index } \\
\text { (HWSI) }\end{array}$ & $\begin{array}{l}\text { Social Water } \\
\text { (SWSI) }\end{array}$ & Water Poverty Index (WPI) \\
\hline Originator & $\begin{array}{l}\text { Falkenmark, Lundqvist and } \\
\text { Widstrand (1989) }\end{array}$ & Leif Ohlsson (1995) & Caroline Sullivan (2002) \\
\hline $\begin{array}{l}\text { Measuring indicator(s) } \\
\text { (criteria) }\end{array}$ & Physical assessments & $\begin{array}{l}\text { Linking hydrological water scarcity } \\
\text { to social conditions }\end{array}$ & $\begin{array}{l}\text { Integrated assessment, linking physi- } \\
\text { cal estimates of water availability with } \\
\text { socioeconomic variables }\end{array}$ \\
\hline Component(s) & Available water per capita and year & $\begin{array}{l}\text { Available water, life expectancy, } \\
\text { adult literacy rate and per capita } \\
\text { GDP }\end{array}$ & $\begin{array}{l}\text { Water Resources, Access, Use, Capac- } \\
\text { ity and Environment }\end{array}$ \\
\hline Assessment nature & Quantitative & Quantitative & Quantitative and qualitative \\
\hline Level of measurement & International/National & International/National & $\begin{array}{l}\text { International/National/ } \\
\text { Regional }\end{array}$ \\
\hline Outcome & Four categories of water situation & Four stages of water availability & Country Ranking \\
\hline
\end{tabular}

Such an index enables national and international organizations concerned with water provision and management to monitor both the resources available and the factors which impact on access and use of those resources (Lawrence et al., 2002).

Sullivan et al. (2006b) introduced potential parameters for use in the construction of a comprehensive and integrated water management index: resources, access, poverty, food security, water quality, environment, capacity, climate and use. Using a methodology comparable to that of the Human Development Index, Sullivan (2002) has constructed an index which measures countries' position relatively to each other in the provision of water. In fact, the WPI contains five major components, each with several sub-components: resources, access, capacity, use and environment (Sullivan et al., 2006a, 2003; Lawrence et al., 2002; Sullivan and Meigh, 2003; Mlote et al., 2002).

We classified the devised indices for assessing the water situation into three generations (Tab. I). A critical review of the three generations indicates some shortcomings. First, the indices are mainly used to assess the water situation at global and national levels. Second, up until the introduction of the WPI, water resources was the sole criterion for assessing water problems. Third, there is a growing awareness that more sophisticated indices are needed to understand better and solve the increasing water problems. Finally, none of the available indices has specifically addressed the crucial issue of water in agriculture. In order to overcome these shortages, any assessment of water scarcity for agriculture can no longer focus on water resources alone, but also has to carefully consider all the various factors which have an effect on the agricultural water situation. In the next section we will introduce the AWPI as a comprehensive index for assessing the agricultural water situation.

\section{AGRICULTURAL WATER POVERTY INDEX}

Based on a classification by Cook et al. (2006), an agricultural system is divided into hydrological, agricultural and livelihood support sub-systems. The well-being that people derive from water therefore depends on the interaction between (a) the water system, that determines availability and reliability of water resources; (b) the agricultural system that converts the water into livelihood support, through food, income or other attributes (water productivity); and (c) the livelihood system that modifies access according to social relations, institutions or organizations. Since the general goal of sustainable water management discourse in agriculture is the improvement of human welfare, which is a complex issue, in this respect a variety of hydrological, economic, social and meteorological indicators are required. Therefore, each index for measuring water poverty in the context of agriculture should involve these aspects simultaneously.

Agricultural water poverty seems to be a result of either natural or human-induced causes (Mehta, 2001; Noemdoe et al., 2006). It occurs when some conditions are met: unavailability of water of a certain quantity and quality; lack of access to agricultural water resources, and inability of water users to effectively use the delivered water. In short, the agricultural water poverty concept relates to quantitative or qualitative depletion in available agricultural water sources. But the fact that the "water poverty" term entitled by a variety of terms indicates different aspects and meanings, dictates that other factors should also be taken into account to have a correct meaning of agricultural water poverty. In this relation, it is important to mention, however, like "water poverty", it is so difficult to offer a clear-cut definition for agricultural water poverty as well. It would be a good idea to consider the factors that should be considered in defining an agricultural water-poor region.

An obvious next step is to develop a complete and simple index for assessing the water situation that can have immediate application at the farm and other spatial levels. The agricultural water poverty index (AWPI) that is presented here is an attempt to construct a farm-level sustainable water management index. The most fundamental function of an agricultural water poverty index (AWPI) must be, however, representing the level of agricultural water poverty as the most important construct that influences agricultural development. 
Table II. Comparison between indicators of the water poverty index (WPI) and the agricultural water poverty index (AWPI).

\begin{tabular}{ll}
\hline Components & WPI indicators \\
\hline Resources & Lawrence et al. (2002): Internal freshwater flows; external in- \\
& flows; population. \\
& Cullis (2005): Per capita yield. \\
& Sullivan et al. (2006a): Assessment of surface water and \\
& groundwater availability using; hydrological and hydrogeolog- \\
& ical techniques; quantitative and qualitative evaluation of the \\
& variability or reliability of resources; quantitative and qualita- \\
& tive assessment of water quality. \\
& Heidecke (2006): Rainfall; Rainfall Variability; Groundwater. \\
& Komnenic et al. (2009): Internal renewable freshwater re- \\
& sources; external freshwater resources and population.
\end{tabular}

Access Lawrence et al. (2002): \% population with access to clean water; \% population with access to sanitation; \% population with access to irrigation adjusted by per capita water resources. Cullis (2005): Percentage of households with access to above RDP level of water supply service.

Sullivan et al. (2006a): Access to clean water as percent households with piped water supply; Reports of conflict over water use; Access to sanitation as percent of population; Percent water carried by women; Time spent in water collection, including waiting; Access to irrigation coverage adjusted by climate and cultural characteristics.

Heidecke (2006): Access to drinking water; Access to sanitary facilities.

Komnenic et al. (2009): percentage of population with safe access to clean water; percentage of population with access to sanitation and irrigation index.

Capacity Lawrence et al. (2002): PPP (purchasing power parity) per capita income; under-five mortality rates; education enrollment rates; Gini coefficients of income distribution.

Cullis (2005): Percentage of households with above threshold income and percentage of population with above Grade 4 education.

Sullivan et al. (2006a): Wealth equivalent to ownership of durable items; Mortality rate for children under 5 years; Educational level; Membership in water users' associations; Percent households reporting illness due to water supply; Percent households receiving a pension, remittances or wages.

Heidecke (2006): Household expenditures; Child mortality; Illiteracy rate; Investments in the water sector.

Komnenic et al. (2009): PPP per capita income; under-five mortality rates and education enrollment rates.
AWPI indicators
- Borehole: The amount of water at the head per hectare of culti- vated land $\left(\mathrm{m}^{3} / \mathrm{ha}\right)$
- Qanat: The product of multiplying the amount of water supply per hour with farmer's share length per hectare of cultivated land $\left(\mathrm{m}^{3} / \mathrm{ha}\right)$
- Spring: The product of multiplying the amount of water supply per hour with farmer's share length per hectare of cultivated land $\left(\mathrm{m}^{3} / \mathrm{ha}\right)$
- Canal Water: Purchased water by farmer per hectare of culti- vated land under canal $\left(\mathrm{m}^{3} / \mathrm{ha}\right)$
- River: the ratio of water withdrawal to the total cultivated land $\left(\mathrm{m}^{3} / \mathrm{ha}\right)$
- Water Right: The ratio of the farmer's water share to the total water shares
- The ratio of the farmer's uncultivated lands due to water scarcity to the total farmer's irrigated lands
- The number of reported conflicts over water use originating from farmer
- Farmer's land situation in water allocation and distribution (up- stream vs. downstream)
- The distance between water source and farm
- Water maintenance status of soils versus water infiltration status (or the ratio of the amount of land with water-maintaining soils to the total amount of farmer's land)

\begin{abstract}
- Productivity of water (WP): The total income from the crop $\times$ per ha per year divided by total water volume used for irrigation per ha $\left(\mathrm{Rial} / \mathrm{m}^{3}\right)$

- The ratio of the farmer's cultivated lands under cash crops to the total amount of irrigated land

- The ratio of farmer's lands under modern irrigation to the total farmer's irrigated lands

- The ratio of the number of water management classes attended to the total number of educational classes held per year with regard to water management

- The ratio of the number of the farmer's membership in water users' associations to the total number of associations related to agricultural water
\end{abstract}

It can also provide a basis for comparison of regions through their agricultural water resources situation, so that water management planning in agriculture can be improved.

Similarly to water poverty, agricultural water poverty encompasses five components: resources, access to water, use, capacity and environment: however, there are basic differences in the definition of these components and the indicators used to assess them.

In the following section a brief description of suggested components and their indicators is provided. Each component can be measured by some indicators that are presented in Table II. Moreover, Table II makes it possible to compare "Water
Poverty Index" and "Agricultural Water Poverty Index" indicators. The table also shows that various researchers have developed diverse indicators for measuring Water Poverty at an international, national or regional level, but the suggested indicators for the AWPI have been recognized to meet agricultural water poverty at the farm and community levels.

\section{AWPI'S COMPONENTS}

A brief description of the five components of the AWPI and their related questions is as follows. 
Table II. Continued.

\begin{tabular}{|c|c|c|}
\hline Components & WPI indicators & AWPI indicators \\
\hline Use & $\begin{array}{l}\text { Lawrence et al. (2002): Domestic water use in liters per day; } \\
\text { share of water use by industry and agriculture adjusted by the } \\
\text { sector's share of GDP. } \\
\text { Cullis (2005): Average per capita domestic water use require- } \\
\text { ment. } \\
\text { Sullivan et al. (2006a): Domestic water consumption rate; } \\
\text { Agricultural water use, expressed as the proportion of irrigated } \\
\text { land to total cultivated land; Livestock water use based on live- } \\
\text { stock holdings and standard water needs; Industrial water use } \\
\text { (purposes other than domestic and agricultural). } \\
\text { Heidecke (2006): Domestic water consumption; Animal water } \\
\text { consumption; Irrigation water use. } \\
\text { Komnenic et al. (2009): Domestic water use in liters per day } \\
\text { and share of water use by industry adjusted by the sector's } \\
\text { share of GDP. }\end{array}$ & $\begin{array}{l}\text { - Farmer's educational level } \\
\text { - Farmer's knowledge level about water resources management } \\
\text { - Being the role model in water management at county level } \\
\text { - The ratio of the farmer's lands with subsurface drainage sys- } \\
\text { tems to the total farmer's irrigated lands } \\
\text { - The ratio of the amount of land leveling to the total farmer's } \\
\text { irrigated lands } \\
\text { - The length of canal and watercourse lining divided by the total } \\
\text { length of canals } \\
\text { - Cultivation of water-saving crops or varieties } \\
\text { - The product of multiplying the amount of farmer's land with } \\
\text { the land value (Rial) } \\
\text { - The ratio of the amount of invested income in rehabilitation of } \\
\text { irrigation system to the total amount of income either from farm } \\
\text { or non-farm } \\
\text { - The ratio of the devoted credits and loans for improving irri- } \\
\text { gation system to the total amount of received credits through last } \\
\text { 3-year period. } \\
\text { - The ratio of the farmer's land under drought insurance to the } \\
\text { total amount of lands }\end{array}$ \\
\hline Environment & $\begin{array}{l}\text { Lawrence et al. (2002): Water quality; water stress (pollution); } \\
\text { environmental regulation and management; informational ca- } \\
\text { pacity; biodiversity based on threatened species. } \\
\text { Cullis (2005): Average present ecological class. } \\
\text { Sullivan et al. (2006a): People's use of natural resources; Re- } \\
\text { ports of crop loss during last } 5 \text { years; Percent households re- } \\
\text { porting erosion on their land. } \\
\text { Heidecke (2006): Forest/protected areas; Fertilizer use; Use of } \\
\text { pesticides; Soil erosion } \\
\text { Komnenic et al. (2009): Water quality, water stress (pollution), } \\
\text { environmental regulation and innovation, informational capac- } \\
\text { ity and biodiversity based on threatened species. }\end{array}$ & $\begin{array}{l}\text { - Water quality (water EC) } \\
\text { - fertilizer consumption per hectare of cultivated land }(\mathrm{Kg} / \mathrm{ha} \text { or } \\
\text { liter/ha) } \\
\text { - pesticide use per hectare of cultivated land (liter/ha) } \\
\text { - The ratio of the plowed lands after cultivation due to water } \\
\text { scarcity to the total cultivated land }\end{array}$ \\
\hline
\end{tabular}

\subsection{Resources}

Resources refer to the amount of water that is currently available in the region. It seeks to answer the question of what water resources and to what extent are they available? This component includes the quantity of surface water and groundwater resources. According to van Cauwenbergh et al. (2007), having a sustainable water system mainly depends on an adequate amount of surface and groundwater and then on satisfying quality. Therefore, this component consists of the amount and quality of agricultural water available in a region. Since the quality of water has a great effect on availability of water for farming, it will be considered in the "environment" component.

\subsection{Access}

Access refers to the extent to which farmers have access to agricultural water resources in the region. It tries to answer this question: what is the extent of water coverage for farmers? This component can be divided into two sections: (2-1) farmers' access to water and (2-2) potential and accessibility of land to available water (see Tab. II).

\subsubsection{Farmers' access to water}

Some of the leading factors that reduce farmers' access to water are related to first, increased demand for agricultural water due to expansion of the population; second, lack of a proper system of rights and institutions that almost always leads to conflicts and overexploitation, especially during the dry season (Mvungi et al., 2005); third, unjust distribution of water among upstream and downstream farmers (Mwakalila, 2006); and finally, improper water resource planning without due consideration of land ownership (Matondo, 2002).

\subsubsection{Potential and quality of land}

The aim of irrigation practice is delivering and distributing water on the field. Even when a farmer has sustainable access to water, the uniformity of water distribution on the farm is not 
guaranteed. There are several factors that affect the distribution of water on the field which is equivalent to low land's access to agricultural water. The water infiltration status of soil, for example, is a factor that reduces the accessibility of land to available water. Other factors that also affect accessibility of land to available water include canal-lining, land leveling, etc.

\subsection{Use}

Use means estimated productivity of the amount of available agricultural water. It implies how effectively water is used by farmers. This component is concerned with the ability of farmers to use agricultural water effectively. The need for more food over the next 50 years calls for agricultural intensification, and the growth of more food with less water (Bossio et al., 2009). So, as water scarcity intensifies in many regions of the word, better management of irrigation water is becoming an issue of paramount importance (Lorite et al., 2007). It is widely agreed upon that water demand should be reduced through increases in water-use efficiency to make irrigated agriculture in the region more sustainable (Lilienfeld and Asmild, 2007). Whereas the traditional irrigation development paradigm is based on providing sufficient water to avoid water deficits at all times to achieve maximum yields (Doorenbos and Pruitt, 1992, cited in: Lorite et al., 2007), the new strategic water development paradigm emphasizes gaining "more use per drop". This means improving the productivity of water (increasing benefits per unit of water consumed) should be captured by the newly designed AWPI. So, a decision that must be made is whether the AWPI will try to reflect productivity in terms of output (product per unit water), value (monetary value per unit of water), or some other measurement of value (jobs per unit of water) (Sullivan et al., 2006b). However, lack of available data for the analysis is an important factor that influences and restricts this selection.

In order to get the most possible benefit from water used, on-farm diversification (e.g. cash crop cultivation) and change in irrigation method (e.g. using pressurized field irrigation) are required.

\subsection{Capacity}

Capacity refers to the farmers' current potential to manage agricultural water at the farm level. It focuses on this question: what is the farmers' capacity to manage water? The AWPI considers this component as having capacity for sustaining access and optimal use of agricultural water and implies the farmer's ability to manage water for the sake of water productivity. Capacity can be divided into three categories: (a) human capital, mostly in the form of farmers' water management knowledge, education and other abilities; (b) real capital, mainly technological and financial (savings and investment); and (c) social capital, which interacts with real capital to provide a capacity to improve water-use efficiency.

As pressure on water resources increases, the need for new approaches to managing this use becomes more pressing (Sullivan, 2002). In order to effectively deliver water to land and make it available for plants, farmers should have a good knowledge of both irrigation water use (irrigation practices, depth and interval among irrigations, etc.) and better adapted cropping systems, particularly in semi-arid environments (Bossio et al., 2009; Lorite et al., 2007). They should also be able to predict the resulting income and water productivity of a given water delivery technique (Lorite et al., 2007). The integration of all these factors in the assessment is a big challenge, and is normally carried out based on farmers' experience and knowledge. What is implied is that those who are able to produce their output levels using the least amount of water are better water managers (Lilienfeld and Asmild, 2007).

As noted earlier, another essential factor in managing water effectively is farmers' technological level. Lack of water resource-conserving farming technologies or poor land leveling, for example, leads to more wasted water in the fields (Mwakalila, 2006).

There is little doubt that better water management in agriculture is likely to have the greatest impact on water resource availability (Sullivan, 2002). In this respect, another important factor is financial capital, which allows improving the agricultural water technologies. There is some evidence that emphasizes income as an important element to help mitigate water poverty (Sullivan and Meigh, 2003; Sullivan et al., 2006a, b; Lawrence et al., 2002; Cullis, 2005; Heidecke, 2006; Komnenic et al., 2009; Sullivan, 2002) and the importance of irrigation in rural well-being, as well (Huang et al., 2006). For example, farmers' poverty level causes reduction in investment in rehabilitation of land or irrigation canals to increase water productivity (Bossio et al., 2009). Poverty can occur because people, to some extent, lack the capacity to use water resources. They might have insufficient land, degraded land, or poor access to market or credit (Cook et al., 2006).

Moreover, some capital such as proper policies or institutional capacities in the water sector must be included in the capacity component. They interact with real capital to provide a capacity to improve water productivity. Hence, the aforementioned capital such as education, income to provide agricultural water technologies, infrastructures, institutional capacity, participation and others which interact with each other indicate a capacity to lobby for and manage a water supply better.

\subsection{Environment}

Environment means environmental factors influencing the quality and quantity of agricultural water. It tries to answer this question: what are the environmental impacts on agricultural water poverty? Today, in many cases, water poverty is increased by ecosystem degradation, and as a result, any index of water poverty should aim to include the status of ecosystems that help sustain levels of water availability (Sullivan, 2002). Water poverty, in the sense of declining water quality as a widespread phenomenon, particularly in arid or semi-arid regions, has forced farmers to use brackish water.

It is emphasized that efficient use of polluting inputs is a prerequisite for sustainability of water resources (De Koeijer 
et al., 2002). Indeed, in the case of agricultural water poverty, land degradation processes have an important negative impact on water productivity. Its rates almost always rise substantially with agricultural activity (Bossio et al., 2009). Therefore, in the absence of direct measurements of agricultural water quality, measurements of land-use pressure might be useful to infer likely impacts on water quality (Sullivan et al., 2006b). The processes such as loss of organic matter and physical degradation of soil, soil surface compaction, and chemical degradation of soil through salinization reduces crop yields and water productivity (Bossio et al., 2009). Thus, they should be considered in the AWPI as important indicators which imply the environmental influences on the quality and quantity of water.

\section{POTENTIAL APPLICATIONS (FUNCTIONS) OF THE AWPI}

This is the first time an agricultural water resource assessment tool has been developed that combines different water-related elements of an agricultural system. This index includes specific components that imply different attributes of sustainable water management issues. It is also an interdisciplinary tool that integrates the key issues relating to water resources, combining agricultural, social, economic and environmental information associated with farmers' ability to get access to water and to use water for productive purposes. The AWPI is designed to provide a transparent and practical tool by which agricultural water stakeholders including farmers, policy-makers, managers, etc. can evaluate the water situation in different locations in a holistic way. This index will allow comparisons to be made between individuals or communities, which enable water-related decisions to be made, comprehensively. It can be used as a useful tool to monitor progress and to identify agricultural areas or communities in most need; thereby it will enable decision-makers to prioritize actions in the water sector. Ranking the agricultural areas based on this criterion helps practitioners to comprise different regions, manage better and conduct water policies in more effective ways.

Moreover, both stakeholders and decision-makers can easily be aware of the current conditions of water in the agricultural system by its descriptive characteristic, because they can easily recognize the real causes of agricultural water poverty by applying the AWPI. The AWPI can be used to find out if water poverty happens through lack of resources, decrease in access to those resources, the use of available water resources with low productivity, or through the lack of knowledge and technological capacities in order to optimize use of water resources.

According to Sullivan et al. (2006a), the measurement of the water situation must be repeated after an appropriate interval in order to assess the changes in water resources in a region over time. The AWPI is also structured to provide a monitoring tool that can be used by agricultural decision-makers at suitable intervals to check if adequate progress towards mitigation of agricultural water poverty is being achieved over a specific period, or else alert them to problems.
Finally, what is important to note is that water is a dynamic and complex resource hard to describe with simple indicators, and that data availability limits the application of more sophisticated indicators. Water problems are often local, while water data are usually available for large scales or even at a national level. These considerations have to be taken into account for developing each index (Rijsberman, 2006). However, indicators must be selected and used carefully if they are to be effective.

\section{WATER AND SUSTAINABILITY OF AGRICULTURE: THE CASE OF IRAN}

Iran's land surface covers 165 million hectares, more than half of which is uncultivable. A total of 14 million hectares is under cultivation at any time, of which about 8 million hectares are irrigated, and the rest are rain-fed (Ehsani, 2005; Keshavarz et al., 2005).

The results of a soil survey and land classification activities in Iran from 1953 to 2000 show that of a total of 20 million hectares of land surveyed, which included most of the cultivated land, only 1.3 million hectares are good-quality land (6.5 percent). The remaining land areas have various degrees of limitations and/or hazards for irrigated farming (FAO, 2005).

Around 70 percent of annual rainfall occurs in 25 percent of the area of the country: most of this area is in north and western Iran, while the rest of the country receives about 30 percent of the total rainfall (Aghaei, 2010). The water shortage is intensified by seasonal rainfall events. Immense seasonal variations in flow characterize Iran's rivers (Chavoshian et al., 2005). The Karun River and other rivers passing through Khuzestan (in the southwest at the head of the Persian Gulf) carry water during periods of maximum flow that is ten times the flow amount in dry periods. The average annual rainfall is about $230 \mathrm{~mm}$, which is well below the world average $(800 \mathrm{~mm})$ (Ehsani and Khaledi, 2004; Gharib, 2003; Kordovani, 1996). Overall, above two-thirds of the country receives less than the average rainfall per year (Chavoshian et al., 2005). Water shortages are compounded by the unequal distribution of water. Only in $1 \%$ of the land, near the Caspian Sea, is the annual rainfall more than $1000 \mathrm{~mm}$, but in the Central Plateau and in the lowlands to the south it varies from less than $50 \mathrm{~mm}$ to $120 \mathrm{~mm}$, far below the 260 to $310 \mathrm{~mm}$ usually required for dry farming; in other parts it varies between 200 and $1000 \mathrm{~mm}$ (Karimi, 2009).

Scarcity of water and the means for making use of it have constrained agriculture since ancient times (Lambton, 1984). To make use of the limited amounts of available water, especially in hot, arid and semi-arid climates, the Iranians' ingenuity centuries ago developed man-made underground water channels called qanats that are still in use (Lahsaeizadeh, 1991; Wulff, 1968). They are usually located at the foot of a mountain and are limited to land with a slope (Foltz, 2002). The main idea for constructing the qanat was to access and transfer groundwater by sinking a series of wells and linking 

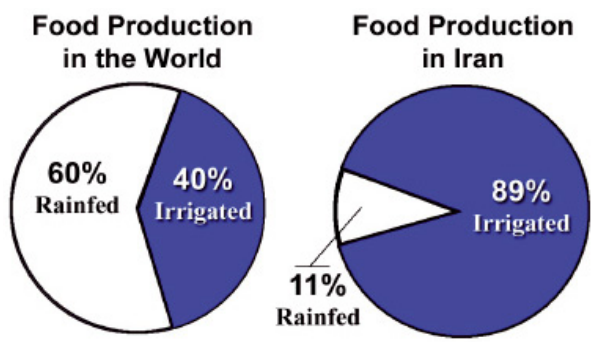

Figure 1. Comparison of food production between irrigated and rainfed agriculture in the world and Iran (Source: Ehsani, 2005, p. 4).

them underground (Khorasanizadeh, 2008). A qanat taps water that has seeped into the ground and channels it via straight tunnels to the land surface. The qanats are designed to surface in proximity to village crops. According to current statistics of the Qanat Information Bank, there are 32698 qanats in Iran.

While sixteen percent of the world's agricultural land are irrigated and produce 40 percent of the world's food, in Iran 44 percent of agricultural land is irrigated and 89 percent of production comes from these lands (FAO, 2008). Figure 1 indicates a comparison of food production between irrigated and rain-fed agriculture in the world and in Iran. Since more than 90 percent of the total annual water consumption in Iran is by agriculture (Soltani, 2009), water is the most important bottleneck and determinant of sustainability of agricultural production. In the next section we provide a brief review of water history in Iran from an agricultural sustainability perspective.

\section{A HISTORICAL PERSPECTIVE OF WATER CHALLENGES IN AGRICULTURE}

Iran's agricultural sustainability with regard to water can be divided into three eras. Each era has its distinct structure, management, technical and environmental issues. The three eras could arbitrarily be called "water conservation", "water exploitation" and "water crisis".

\subsection{Water Conservation Era (up to land reform of 1961)}

Since ancient times water has been the most important determinant of agriculture in Iran. Access to water has been the essential factor in geographical distribution and settlement of rural populations (Lambton, 1984; Keshavarz et al., 2005). The characteristic features of this era were:

1. Water was conserved particularly as underground water. Despite water scarcity farmers lacked the technological know-how to exploit water resources beyond the conservation threshold. The qanat system was not able to extract underground water deeper than certain points where people could drill well.

2. Agricultural productivity was low. Because of the low population, and low standards of living and consumption, demand for food was low (Rezaei-Moghaddam et al.,
2005). In addition to water there were other limiting factors such as traditional technology (use of human and animal power), pest and diseases, etc., which limited production (Abdollahi, 1999; Lahsaeizadeh, 1991).

3. The production system was a subsistence peasant-landlord system (Lahsaeizadeh, 1991). The water system was managed by a powerful landlord who owned the water resources (Sfandyari, 2001). Water was more or less distributed equally among the peasants of one landlord. Therefore, there was a common benefit in preserving the water flow. Under these circumstances peasants provided the workforce with all its hardship, with little or no resistance (Katuzian, 1998). There was no major peasant revolt during this era. The water management system was efficient, considering the level of the technological know-how of this era.

4. Water-use efficiency was rather low due to traditional irrigation methods. With few exceptions, surface irrigation was the primary water distribution method.

5. Water quality was high because there were no industrial or agricultural chemicals to pollute the water.

6. Water resources were managed sustainably during this era (Foltz, 2002).

\subsection{Water Exploitation Era (from land reform up to self-sufficiency in wheat production of 2004)}

After the land reform the close rural production system drastically changed. Transfer of exogenous technologies and inputs to the agricultural system was later facilitated by increased revenue from export of oil (according to statistics, Iran ranks among the world's top three holders of both proven oil and natural gas reserves). This era is characterized as follows:

1. Although before the land reform, 70 percent of agricultural water was provided by qanats (Doosti Sani, 2001; Rezaei-Moghaddam et al., 2005), introduction of water pumps and dams reduced the role of qanats to a great extent (Kordovani, 1996; Foltz, 2002; Karimi, 2009). Many qanats were dried and water pumps, which did not have some of the limitations of qanats, became the technology of the day. It is estimated that there are about 500000 deep and shallow wells and also the same amount of handexcavated open wells with a capacity of 59 billion cubic meters in the country. In addition, exploitation of groundwater by uncontrolled excavated wells and inappropriate usage of the existing wells has resulted in water depletion and water draw down (Karimi, 2009). Therefore, the new technology provided the opportunity to exploit water resources well beyond a sustainable level (Amin et al., 2001; Ekhtesasi et al., 2001; Kordovani, 1996).

2. The combination of the so-called green revolution and land reform had a profound impact on this stage of agricultural development in Iran. The traditional production system (peasant landlord system) was not functional anymore (Safinejad, 1990). The Buneh cooperative system was replaced by individual family farms that were competing for resources, particularly water (Katuzian, 1998; 
Increasing fertilizer use in Iran since 1961

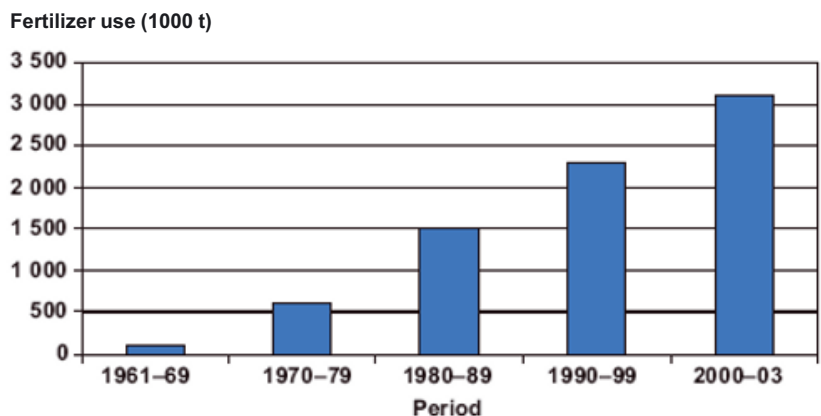

Figure 2. Trends in fertilizer consumption changes during the Water Exploitation Era in Iran (Source: FAO, 2005).

Safinejad, 1990). Transfer of new technology made it possible for farmers to rapidly expand the area under cultivation (Rezvani, 2005). The high external input agriculture, chemical fertilizers (the trend for fertilizer consumption after the green revolution in Iran is shown in Fig. 2), pesticides, herbicides (the usage of herbicide during 19942004 was increased by about 71\%, Deihimfard et al., 2007) and high-yielding varieties increased the level of productivity. Along with all these changes there was an increasing water demand with very little recharge, which caused a severe decline in water availability (Karimi, 2009; Madaeni and Ghanei, 2004; Yadghar, 2003).

3 . This is the era in which the "tragedy of the commons" (Deese, 2008; Hayati and Karami, 2005) was materialized with regard to Iran's water resources.

4. In response to the increasing water demand new dams were built (according to the Energy Ministry of I. R. Iran (2006) during the period of 1948-1979 only 13 reservoir dams and 552000 hectare irrigation and drainage networks were built, whereas from 1979 to 2006 they were increased to 167 and 1087800 , respectively), and new wells were drilled (Kordovani, 1996) but little was done to increase water-use efficiency.

Average groundwater discharge varied from less than $20 \mathrm{~km}^{3} /$ year in the early $1970 \mathrm{~s}$ to over $74 \mathrm{~km}^{3} /$ year at the end of 2000. The number of wells during this period increased fivefold, from just over 9000 to almost 45000 (FAO, 2008). Despite the benefits of hydropower and irrigation, social and environmental costs always coincide with development of large dams (Mehta, 2001). As a result of upstream dams many natural lagoons and small lakes which were vital to environmental preservation of plant and animal species in a dry region were irreversibly damaged. Exploitation of groundwater through drilling deeper and deeper wells reduced the level of groundwater to critical levels. Since 1999 Iran has faced a severe water crisis (Foltz, 2002). The groundwater balance shows that there was a difference of $4.8 \mathrm{bcm}$ between recharge of groundwater resources $(56.5 \mathrm{bcm})$ and their discharge $(61.3 \mathrm{bcm})$. The average drawdown of the water table in 168 plains of the country, from which 73 percent of all withdrawals occur, was more than 1 meter per year. As a consequence, over $50 \%$ of the groundwater storage has been depleted, particularly in some eastern provinces (Alizadeh and Keshavarz, 2005). Indeed, a related effect of groundwater pumping was the lowering of groundwater levels below the depth that streamside or wetland vegetation needs to survive. The overall effect was a loss of vegetation and wildlife habitat.

5. Among the consequences of groundwater level declines were increased pumping costs (Fathi and Zibaei, 2009), deterioration of water quality, especially groundwater (Karimi, 2009; Jalali and Kolahchi, 2008), reduction of streamflow in rivers during dry periods (Fathi and Zibaei, 2009; Faramarzi et al., 2009), decreased fresh-water inflows to lakes (there is more of an interaction between the water in lakes and rivers and groundwater than often assumed), land subsidence (Karimi, 2009), diminished availability of groundwater for withdrawal during times of drought, and decreased availability of the water resources for future generations.

6. Demand for food by an increasing population combined with a national desire to achieve self-sufficiency in crop production, particularly wheat, increased cultivated land (Yadghar, 2003; Faramarzi et al., 2009). There were great attempts to expand irrigation capacity in farms. However, irrigation is very expensive and highly subsidized. Much of the newly irrigated land is used to grow wheat, at a cost higher than that of imported wheat, but it is seen as a means of reducing the country's dependence on imports and for improving food security. Finally, as a result, in 2004 the government officially announced self-sufficiency in wheat production. During a 16-year period, from 1988 to 2004, the production of wheat increased from 7.3 to 13.5 million tons. Although the total production of wheat increased during this era, recently due to water shortage it decreased to 9.8 million tons in 2008 , and due to this situation Iran was forced to import 5-6 million tons of wheat in 2008-09 (Fars News Agency, 2010; Iran's wheat information network, 2009; Karami, 2009).

7. Farmers and experts found themselves in control of nature and particularly water resources and any concerns regarding the limitation of water resources was dismissed as pessimistic. They imagined that what they faced was a passing crisis and not a permanent trend (Foltz, 2002).

\subsection{Water Crisis Era (after self-sufficiency in wheat production)}

The short-lived self-sufficiency in wheat production marks the beginning of this era. Unsustainable exploitation of water resources combined with frequent national drought provided an era marked by:

1. Increased awareness among experts that the current water situation is critical and unsustainable. Although there was general agreement about the presence of the crisis there are differences regarding the solutions and some professionals 
may even think that there is no viable solution. The issues raised by experts are interesting, thought-provoking, sometimes even frightening, but most of all crucial to national policies. Genuine concerns about maintaining agricultural sustainability of the country in the future have been expressed.

2. The number of abandoned villages due to lack of water is on the rise. For example, in 2003 about 86 villages in Zabol County in Sistan Baluchistan province in the SouthEastern part of Iran were evacuated for lack of water and drought (Beik Mohammadi et al., 2006). Rural to urban immigration is noticeable.

3. Although due to oil revenues and import of agricultural products the urban population has not felt the burden of past agricultural policies and practices, the farmers are facing increasing pressure. The government attempts to provide relief through economic planning (Ehsani, 2005). Crop insurance and aid have increased dramatically (according to statistics presented by the Family and Women's Affairs Center website in 2009, relief funds that were paid to farmers increased from 1700 billion Rials in 2004 to 4557 B Rials in 2009, which is about 2.68 times as much as relief funds paid in 2004); however, the ability to sustain these efforts in the future is in question.

4. Despite some measures such as promotion of greenhouses, pressurized irrigation systems (about $5 \%$ of total irrigated land, FAO, 2008) and improvement in agricultural practices water efficiency is still very low. Irrigation efficiency is generally low (around 30 percent at the national level, Soltani, 2009). It is also anticipated that a one percent increase in water efficiency could save $800 \mathrm{mcm}$ (million cubic meters) of water in Iran, which results in the irrigation of an additional 8000 hectares of the agricultural areas (Ehsani, 2005). Because of the improper shape and size of the farms, lack of suitable irrigation methods, low price of irrigation water, traditional methods of irrigation, leakage of the main and branch canals, and lack of proper monitoring (Ehsani, 2005; Gharib, 2003), many academics and other experts in Iran insist that mismanagement of water resources is a significant cause of the water crisis (Foltz, 2002).

5. Thus far, the agricultural sector has not been able to deal successfully with the problem of water scarcity. It seems that past solutions are inadequate in solving immense water problems from overexploitation caused by ignorance, mismanagement and the impact of the growing population. In fact, rapid population increase is the most important factor of per capita renewable water decrease during the last 80 years (Babran and Honarbakhsh, 2008). Iran's population has dramatically increased during the past six decades. It was around 19.5 million in 1961, and increased to 34 million in 1979 and then to above 70 million in 2007 (source: Iran's Population Census (2007) available online at http://amar.sci.org.ir/PlanList.aspx). Because of severe exploitation of aquifers and decreasing available water, water has been diverted from the agricultural sector to drinking supplies in recent years, especially in critical areas (Mousavi, 2005). As pressure on water resources increases, the need for new approaches to managing this use becomes more pressing (Sullivan, 2002). Looking to the future, there is a growing need for new paradigms, approaches, visions and methods to solve the present problems. The agricultural water poverty framework proposed in this paper can provide a new look at the problem of agricultural water and a vision to find alternative solutions.

\section{AGRICULTURAL WATER POVERTY ANALYSIS OF IRAN'S AGRICULTURE}

The sustainability of Iran's agriculture system during the three eras described above will be analyzed using the agricultural water poverty framework (Fig. 3). Each era will be analyzed with regard to the five components of agricultural water poverty (Tab. III):

Resources: In a dry and semi-dry region such as Iran water resources are a major determinant of agricultural sustainability. Although due to climatological conditions the water resources were at a medium level, during the "conservation era" water resources remained intact because even with extensive use of qanats farmers did not have the means to exploit water beyond sustainability. During this era farmers felt that nature was in control of their farming practices and they had to adapt to what nature had to offer. However, these conditions rapidly and radically changed during the "water exploitation era". For the first time in history new technology provided the opportunity to exploit water resources well beyond sustainable thresholds. Agricultural chemicals, often over-used (Karami and Ebrahimi, 2000), polluted water resources. Consequently, during this era the rate of water extraction well exceeded the natural recharge and a rapid decline in water resources both quantitatively and qualitatively was observed. The "crisis era" started with deep concern regarding the low quantity of water resources. Water resources in most parts of the country are inadequate to meet the increasing demand; needless to say, several years of drought have also contributed to this. However, the real crisis is not a temporary, drought-related problem (Foltz, 2002).

Access: This component is concerned with farmers' access to water and the quality of land with regard to waterholding capacity and irrigation. Access should be evaluated relative to demand. There was a moderate access to water during the "conservation era" because the surface water and the qanat system provided relatively adequate water to irrigate the limited agricultural land made cultivatable by traditional technologies of the day. Of course, the level of living and consumption adjusted themselves to the level of production. However, during the "exploitation era" the agricultural production system increased its production commensurate with the improving level of living standards and consuming. Access to water through drilling deep wells increased to meet the demand without due consideration to sustainability of water resources. The peak of access was during the short-lived wheat self-sufficiency period. Therefore, this era is marked by an increasing level of access. Although during the "crisis era" the 


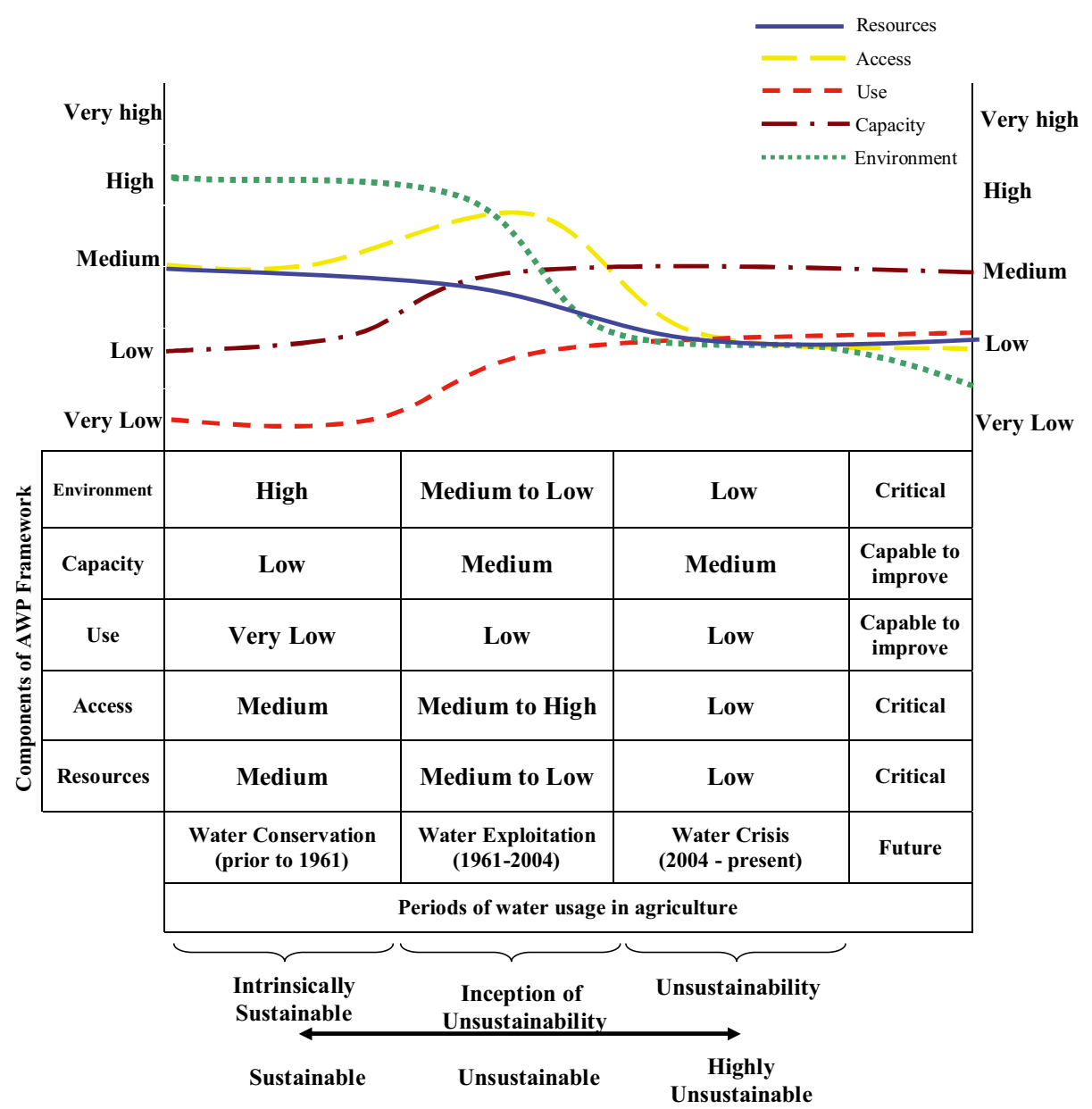

Figure 3. The trend of agricultural water sustainability in Iran.

infrastructure for access was available, lack of water resources made it irrelevant. The land area under wheat production reduced considerably and as a result, import of food crops increased significantly.

Use: Water-use efficiency was very low during the "conservation era". Surface irrigation was used with very low efficiency. Technologies of the "exploitation era" helped farmers improve their water-use efficiency. Although compared to the previous era water-use efficiency had improved relatively, the agricultural system was criticized for poor water-use efficiency. The water-use efficiency in the "crisis era" is still low. This component is important in future development of Iran's sustainable water management because it is one of the limited areas where the opportunity for improvement lies. More efficient use of water through establishment of greenhouses, pressurized irrigation systems, reuse and unconventional water are considered to be the future of water management.

Capacity: The capacity is understood as knowledge, technological capacity and capital (monetary/non-monetary) to manage water. The capacity was low during the "conservation era": the indigenous knowledge and technology regarding water management, although appropriate for the time and place, was backward by present standards. The capacity improved to medium level during the "exploitative era" and remained the same in the "crisis era". This is the second area where great potential for improvement toward sustainable water management exists.

Environment: Surface and groundwater were well conserved during the "conservation era" because farmers did not have any chemical fertilizers or pesticides to pollute the water. Use of external inputs decreased the quality of surface and groundwater in the second era. So the trend of environmental impacts moved from high to medium, and low in the "conservation era" and "crisis era", respectively. Due to higher consumption of chemical inputs, salinization of lands and continuous periods of drought, ecological concerns with regard to water resources were increased during the "crisis era".

The "conservation era" could be called intrinsically sustainable because the agricultural system had the ability to maintain production and serve its intended purpose with internal inputs, and more than everything else without overexploitation of water resources. The system could be called a passive production system. An important quality of this passive production system was resiliency. The production system could respond easily to change in use and climate. By its nature, the production system of this era was passive, resilient and therefore 
Table III. Iran's Agriculture situation during three eras with regard to the agricultural water poverty (AWP) framework.

\begin{tabular}{|c|c|c|c|}
\hline Periods & Water conservation (prior to 1961 ) & Water exploitation (1961-2004) & Water crisis (2004 - present) \\
\hline \multicolumn{4}{|l|}{ Components } \\
\hline Resources & $\begin{array}{l}\text { Mixture of surface and groundwater re- } \\
\text { sources; adequate water from traditional } \\
\text { resources, i.e. rivers, qanats, springs }\end{array}$ & $\begin{array}{l}\text { Mixture of surface and groundwater re- } \\
\text { sources; dominance of deep, shallow and } \\
\text { hand-excavated open wells }\end{array}$ & $\begin{array}{l}\text { Mainly groundwater resources, i.e. } \\
\text { deep and semi-deep wells, decrease in } \\
\text { rain amount due to precipitation pat- } \\
\text { tern changes }\end{array}$ \\
\hline Access & $\begin{array}{l}\text { Low population and high flexibility in se- } \\
\text { lecting land for cultivation, partly equal } \\
\text { distribution of water among peasants }\end{array}$ & $\begin{array}{l}\text { High population, expansion of individual } \\
\text { family farms, increased cultivated land, } \\
\text { increased water demand and competition } \\
\text { for water, structural reforms and land } \\
\text { fractions, depletion of groundwater stor- } \\
\text { age }\end{array}$ & $\begin{array}{l}\text { Higher population, high conflict on } \\
\text { water resources (especially in arid ar- } \\
\text { eas), reduced water supply for irri- } \\
\text { gation, severe exploitation of aquifers } \\
\text { and decreasing available water, re- } \\
\text { duced level of groundwater to critical } \\
\text { levels }\end{array}$ \\
\hline Use & $\begin{array}{l}\text { Subsistent and small-scale production } \\
\text { system, low cultivated land, low agricul- } \\
\text { tural productivity, low extraction \& very } \\
\text { low water-use efficiency }\end{array}$ & $\begin{array}{l}\text { Dominance of growth-oriented and semi- } \\
\text { commercial views in agriculture, high ex- } \\
\text { ploitation of water resources, low water- } \\
\text { use efficiency }\end{array}$ & $\begin{array}{l}\text { Growth-oriented and commercial } \\
\text { views in agriculture, extreme ex- } \\
\text { traction and overexploitation of } \\
\text { groundwater, consistency or de- } \\
\text { crease in cultivated areas, low water } \\
\text { productivity }\end{array}$ \\
\hline Capacity & $\begin{array}{l}\text { Farmers' participation, landlord manage- } \\
\text { ment and investment, use of local and tra- } \\
\text { ditional technology (human and animal } \\
\text { power) for water extraction, lack of farm- } \\
\text { ers' technological knowledge to exploit } \\
\text { high amount of water, traditional deliver- } \\
\text { ing canals and irrigation methods }\end{array}$ & $\begin{array}{l}\text { Individual peasant management, mix } \\
\text { of traditional and modern irrigation } \\
\text { systems, promotion toward diffusion of } \\
\text { pressurized irrigation systems, expanded } \\
\text { irrigation technological capacity, high } \\
\text { subsidization in irrigation sector, more } \\
\text { and less struggles for rehabilitation of } \\
\text { water system, beginning of attention to- } \\
\text { ward water crisis in agricultural extension } \\
\text { activities }\end{array}$ & $\begin{array}{l}\text { Increased pumping costs, need to in- } \\
\text { crease water management knowledge } \\
\text { and technologies, increased govern- } \\
\text { mental investment and emphasis on } \\
\text { crop insurance, increasing pressurized } \\
\text { irrigation systems, severe need for } \\
\text { land improvement and water system } \\
\text { rehabilitation, concentration of agri- } \\
\text { cultural extension activities on water } \\
\text { management, development of agricul- } \\
\text { tural water-related associations }\end{array}$ \\
\hline Environment & $\begin{array}{l}\text { High water quality due to lack of indus- } \\
\text { trial and chemical pollutants }\end{array}$ & $\begin{array}{l}\text { High usage of external inputs, deteriora- } \\
\text { tion of water quality especially ground- } \\
\text { water and land destruction, damaging } \\
\text { of natural lagoons and small lakes, de- } \\
\text { creased fresh-water inflows to lakes, loss } \\
\text { of vegetation and wildlife habitat, more } \\
\text { frequency of drought periods due to cli- } \\
\text { mate changes }\end{array}$ & $\begin{array}{l}\text { Higher consumption of chemical in- } \\
\text { puts, salinization of lands, increased } \\
\text { ecological concerns with regard to wa- } \\
\text { ter resources, continuous periods of } \\
\text { drought }\end{array}$ \\
\hline
\end{tabular}

intrinsically sustainable. The farmers 'unlearned' the passive production system with the introduction of the green revolution, which enabled high production with high external inputs and extraction of as much groundwater as possible. From a sustainability point of view the "water exploitation" era could be called the period of inception of unsustainability. This is the era of the active production system where the goal was to increase production with technologies that enable farmers to extract water to meet the demand without concern for limitation of the supply side. The resilience of the active production system was much lower than the previous era. Given the systemic forces of climate disruption and limited water resources, it can be said that the agricultural production of this era progressively lost its resiliency. The question of the 'crisis era' is: can the agriculture system sustain itself by using the existing ideas and practices? Based on the above analysis it can be concluded that there is real doubt about the sustainability of this era. Future prospects and possible solutions for sustainability of Iran's agriculture lies in a water management system that can incorporate the analysis of components of the AWPI presented above into its management system.

\section{CONCLUSION}

Water is viewed as a pivotal factor to augment income in rural areas because it increases agricultural productivity. The lack of access to water has major impacts on people's wellbeing. Over the last two decades, agricultural sustainability has gained increased recognition as a fundamental component of sustainable development. It is emphasized that research on sustainability of agriculture should take into account social, environmental and economic dimensions through specific indicators. This paper reveals that water directly impacts all the dimensions of agricultural sustainability. Although water is an important component in measuring sustainability of each 
agricultural system, it was not acknowledged well by specific and integral available indicators. Moreover, increased demand on water supply, mainly due to the growing population, has made clear the need to address both equity in water allocation and water-use efficiency. This paper concludes that sustainable water management is a major necessity for sustainable agriculture, especially in arid and semi-arid regions. In this way, successful water assessment as a prerequisite for sustainable water management plays a significant role in sustainability of agriculture. Various researchers have advised different indices to assess the water situation, mostly at national or international levels. A critical review of these indices indicates some shortcomings that are explained in this paper. It is important to note that the national analysis of water scarcity is of very limited use in assessing whether individuals or communities are water-poor. Furthermore, any assessment of water scarcity for agriculture has to look carefully at the all various factors which have an effect on the agricultural water situation. The AWPI was introduced as a new index which includes five components (i.e. resources, access, use, capacity and environment) to assess the water situation in agriculture, particularly in places where water supply may currently be limited.

Providing stakeholders with a practical tool to monitor the water situation properly is of great value, that is addressed perfectly by the AWPI. Indeed, ranking communities or farmers based on their agricultural water poverty can help decisionmakers in future planning.

The AWPI is a constructive tool in sustainable water management; it can be used to understand the sustainable trend in the agricultural system. Linking water management and sustainability analyses of the agricultural system via the agricultural water poverty framework has proved to be an attractive explanation of how water plays an important role to achieve sustainability in agriculture. This is illustrated by the case of Iran, where water is physically scarce. With regard to the agricultural water poverty framework, Iran's agriculture sector can be considered through three eras: water conservation, water exploitation and water crisis. During the "conservation era", due to use of internal inputs and a subsistence agricultural system, water resources were not overexploited. This era is characterized by low water-use efficiency and could be called intrinsically sustainable. It has became clear that Iran's agriculture has experienced an increasingly unsustainable situation in water management after this era. Introduction of the green revolution's technologies led farmers to high use of external inputs and overexploitation of water resources. This era was the beginning of unsustainability with regard to water. The main feature of Iran's agriculture during the crisis era has been the unsustainability, that has raised many doubts about sustainability in the future. During this era three components of the agricultural water poverty framework, namely resources, access and environment, have reached critical levels that need to be more protected in the future. But under the current circumstances of climate disruption, and limited water resources, areas related to capacity could be improved; in other words, it can be achieved by increasing farmers' water management knowledge and technological level. This is in fact the heart of the matter for future sustainable water management through more efficient use of available water resources. Finally, it can be concluded that the case of Iran indicates the usefulness of the AWPI well for analysis of agricultural water problems and providing possible solutions.

Acknowledgements: This research was supported in part by the Iran National Drought Research Institute, Shiraz University, Shiraz, Iran, under grant No. 333PG.

\section{REFERENCES}

Abalu G., Hassan, R. (1998) Agricultural productivity and natural resource use in Southern Africa, Food Policy 23, 477-490.

Abdollahi M. (1999) Comparative study of agricultural utilization systems and evaluation of their performance to recognize the types and characteristics of the optimal utilization systems in Iran, Department of Utilization System, Ministry of Jihad-e-Keshavarzi Press, Tehran, Iran (in Farsi).

Aghaei M. (2010) Increasing productivity through water resource management and the role of agriculture bank to afford drainage and irrigation network projects, in: New Participation Approaches at Study, Construction, Usage and Maintenance of Drainage and Irrigation Networks, Proc. 1st National Congress, Shiraz, 27-28 January 2010, Iran (in Farsi).

Aistars G.A. (1999) A life cycle approach to sustainable agriculture indicators, Workshop Proc. 26-27 February 1999, University of Michigan, Dana Building the Center for Sustainable Systems, pp. 1-118.

Alizadeh A., Keshavarz A. (2005) Status of agricultural water use in Iran, in: Proc. Workshop "Water Conservation, Reuse, and Recycling", National Academies Press, Washington, DC.

Amin S.A., Sadeghi M.M.J., Salimi M.A. (2001) Water reserve engineering in qanats and its economical study, in: Qanat, Proc. National Conference, Yazd, Iran, pp. 277-292 (in Farsi).

Babran S., Honarbakhsh N. (2008) The crisis of water situation in the world and Iran, Q. J. Rahbord 16, 193-212 (in Farsi).

Beik Mohammadi H., Noori H., Bazrafshan J. (2006) The effects of drought of 1999-2005 on Sistan rural economy and copping strategies, J. Geogr. Dev. 3, 53-72 (in Farsi).

Bossio D., Geheb K., Critchley W. (2009) Managing water by managing land: addressing land degradation to improve water productivity and rural livelihoods, Agric. Water Manage. 97, 536-542.

Bucks D. (1991) Improvements in agricultural water management (Chap. 16), in: Managing Water Resources in the West Under Conditions of Climate Uncertainty, Proc. Commission on Geosciences, Environment, and Resources (CGER), National Academy Press, Washington, DC.

Chavoshian S.A., Takeuchi K., Funada S. (2005) An overview to transboundary and shared water resources management in Iran, technical challenges and solutions, in: The Role of Water Sciences in Transboundary River Basin Management, Proc. Thailand, pp. 189195.

Cook S.E., Gichuki F., Turral H., Fisher M.J. (2006) Analyzing water poverty: water, agriculture and poverty in Basins, Basin Focal Project Working Paper, No. 3, pp. 1-18.

Cullis J. (2005) Water poverty mapping: development and introduction using a case study at the local municipal scale for the Eastern Cape, Working Report to the Water Research Commission, WRC TT 250/05, Republic of South Africa.

Deese R.S. (2008) A metaphor at midlife: 'the tragedy of the commons' turns 40, Endeavour 32, 152-155. 
Deihimfard R., Zand E., Damghani A.M., Soufizadeh S. (2007) Herbicide risk assessment during the wheat self-sufficiency project in Iran (Abstract), Pest Manag. Sci. 63, 1036-1045.

De Koeijer T.J., Wossink G.A.A., Struik P.C., Renkema J.A. (2002) Measuring agricultural sustainability in terms of efficiency: the case of Dutch sugar beet growers, J. Environ. Manage. 66, 9-17.

Doosti Sani M. (2001) The role of qanat to develop the eastern regions, in: Qanat, Proc. National Conference, Yazd, Iran, pp. 25-37 (in Farsi).

Ehsani M. (2005) A vision on water resources situation, irrigation and agricultural production in Iran, ICID 21st European Regional Conference, Frankfurt (Oder) and Slubice-Germany and Poland.

Ehsani M., Khaledi H. (2004) Water productivity in agriculture, National Committee of Irrigation and Drainage Publications, Tehran Iran (in Farsi).

Ekhtesasi M.R., Mehrabi A.A., Daneshvar M.R. (2001) Deterioration of water resources as an indicator of unsustainable development at Yazd-Ardakan plain (Factors and processes), in: Sustainable Development at Desert Ecology, Proc. Regional Conference, 2729 May 2001, Yazd, Iran (in Farsi).

Energy Ministry of I.R. Iran (2006) Water as development core, Fourth Development Program, Article No. 17, Department of Water Affairs, Tehran, Iran (in Farsi).

Faramarzi M., Abbaspour K.C., Schulin R., Yang H. (2009) Modelling blue and green water resources availability in Iran, Hydrol. Process. 23, 486-501.

Fars News Agency (2010) The prediction of increase in production of five crop, agriculture and livestock domain, Work Report, No. 8803170290, 02/17/2010 (in Farsi).

Fathi F., Zibaei M. (2009) Exploitation management of groundwater: the case of Firoozabad Plain, in: Drought Problems and Copping Strategies, Proc. National Conference, 23-24 May 2009, Shiraz University, Agricultural College, Shiraz, Iran (in Farsi).

Foltz R.C. (2002) Iran's water crisis: cultural, political and ethical dimensions, J. Agr. Environ. Ethic. 15, 357-380.

Food and Agriculture Organization (FAO) (2005) Fertilizer use by crop in the Islamic Republic of Iran, Food and Agriculture Organization of the United Nations, Rome.

Food and Agriculture Organization (FAO) (2008) Helping to build a world without hunger, Summary Fact Sheet, Islamic Republic of Iran, aquastat, global information system on water and agriculture, Profile as published in Water Report No. 34.

Gafsi M., Legagneux B., Nguyen G., Robin P. (2006) Towards sustainable farming systems: effectiveness and deficiency of the French procedure of sustainable agriculture, Agric. Syst. 90, 226-242.

Gharib Y. (2003) Water as a source of food security, Jihad 22, 6-11 (in Farsi).

Golusin M., Munitlak Ivanovic O. (2009) Definition, characteristics and state of the indicators of sustainable development in countries of Southeastern Europe, Agr. Ecosyst. Environ. 130, 67-74.

Gómez-Limón J.A., Riesgo L. (2009) Alternative approaches to the construction of a composite indicator of agricultural sustainability: an application to irrigated agriculture in the Duero basin in Spain, J. Environ. Manage. 90, 3345-3362.

Hamdy A., Ragab R., Scarascia-Mugnozza E. (2003) Coping with water scarcity: water saving and increasing water productivity, Irrigation Drainage 52, 3-20.

Hanley N., Moffatt I., Faichney R., Wilson M. (1999) Measuring sustainability: a time series of alternative indicators for Scotland, Ecol. Econ. 28, 55-73.

Hayati D., Karami E. (2005) Typology of causes of poverty: the perception of Iranian farmers, J. Econ. Psychol. 26, 884-901.
Heidecke C. (2006) Development and evaluation of a regional water poverty index for Benin, Environment and production technology division, EPT Discussion Paper, International Food Policy Research Institute, Washington, DC.

Hengsdijk H., Guanghuo W., Van den Berg M.M., Jiangdi W., Wolf J., Changhe L., Roetter R.P., van Keulen H. (2007) Poverty and biodiversity trade-offs in rural development: a case study for Pujiang County, China, Agric. Syst. 94, 851-861.

Huang Q., Rozelle S., Lohmar B., Huang J., Wang J. (2006) Irrigation, agricultural performance and poverty reduction in China, Food Policy $31,30-52$.

Ioris A.A.R., Hunter C., Walker S. (2008) The development and application of water management sustainability indicators in Brazil and Scotland, J. Environ. Manage. 88, 1190-1201.

Jalali M., Kolahchi Z. (2008) Groundwater quality in an irrigated, agricultural area of northern Malayer, Western Iran, Nutr. Cycl. Agroecosyst. 80, 95-105.

Karami E. (2009) Drought management: the role of knowledge and information system, in: Drought Problems and Copping Strategies, Proc. National Conference, 23-24 May 2009, Shiraz University, Agricultural College, Shiraz, Iran (in Farsi).

Karami E., Ebrahimi H.R. (2000) Over fertilization with phosphorous in Iran: an sustainability problem, J. Extension Syst. 16, 100-120.

Karimi A.A. (2009) Water situation in Iran: challenges and achievements, in: European Water and Sanitation Services vs. Sustainable Development, Potable Water Services in Morocco-China-AustriaIran, Proc. November, 2009, Athens.

Katuzian M.A.H. (1998) Nine essays on the historical sociology of Iran, oil and economic development, 1st ed., Nashr-e Markaz, Tehran, Iran (in Farsi).

Keshavarz A., Ashraf Sh., Hydari N., Pouran M., Farzaneh E. (2005) Water allocation and pricing in agriculture of Iran, in: Proc. Workshop "Water Conservation, Reuse, and Recycling", National Academies Press, Washington, DC.

Khorasanizadeh Sh. (2008) Novel hydraulic structures and water management in Iran: a historical perspective, in: Water Culture and Water Conflict in the Mediterranean Area, Options Mediterraneennes, Proc., pp. 25-43.

Komnenic V., Ahlers R., van der Zaag P. (2009) Assessing the usefulness of the water poverty index by applying it to a special case: can one be water poor with high levels of access? Phys. Chem. Earth. 34, 219-224.

Kordovani P. (1996) Resources and problems of water in Iran, Forth Ed., Tehran University Publication, Tehran, Iran (in Farsi).

Lahsaeizadeh A.A. (1991) Social changes in Iran's villages, 1st ed., Navid-e-Shiraz Publications Ltd., Shiraz, Iran (in Farsi).

Lambton A.K.S. (1984) Landlord and peasant in Persia, 3th ed., Center of scientific and cultural publications, the Ministry of Culture and Higher Education, Tehran, Iran (in Farsi).

Lawrence P., Meigh J., Sullivan C. (2002) The water poverty index: an international comparison, Keele Economics Research Papers, KERP 2002/19, Centre for Economic Research, Keele University, United Kingdom, pp. 1-19.

Lilienfeld A., Asmild M. (2007) Estimation of excess water use in irrigated agriculture: a data envelopment analysis approach, Agr. Water Manage. 94, 73-82.

Lorite I.J., Mateos L., Orgaz F., Fereres E. (2007) Assessing deficit irrigation strategies at the level of an irrigation district, Agr. Water Manage. 91, 51-60.

Madaeni S.S., Ghanei M. (2004) Reverse osmosis as a solution for water shortage in Iran, in: Water Resources \& Arid Environment, Proc. International Conference, pp. 1-5. 
Malkina-Pykh I.G., Pykh Y.A. (2008) Quality-of-life indicators at different scales: theoretical background, Ecol. Indic. 8, 854-862.

Maneta M.P., Torres M., Wallender W.W., Vosti S., Kirby M., Bassoi L.H., Rodrigues L.N. (2009) Water demand and flows in the Sa ${ }^{2}$ Francisco River Basin (Brazil) with increased irrigation, Agr. Water Manage. 96, 1191-1200.

Matondo J.I. (2002) A comparison between conventional and integrated water resources planning and management, Phys. Chem. Earth. 27, 831-838.

Mehta L. (2001) The manufacture of popular perceptions of scarcity: dams and water-related narratives in Gujarat, India, World Dev. 29, 2025-2041.

Mlote S.D.M., Sullivan C., Meigh J. (2002) Water poverty index: a tool for integrated water management, in: Water Demand Management for Sustainable Development, Proc. 3rd Symposium, Dar es Salaam, 30-31 October 2002.

Mousavi S.F. (2005) Agricultural drought management in Iran, in: Proceedings of an Iranian-American Workshop on Water Conservation, Reuse, and Recycling, National Academies publications, Washington, DC

Mvungi A., Mashauri D., Madulu N.F. (2005) Management of water for irrigation agriculture in semi-arid areas: problems and prospects, Phys. Chem. Earth. 30, 809-817.

Mwakalila Sh. (2006) Socio-economic impacts of irrigated agriculture in Mbarali district of South-West Tanzania, Phys. Chem. Earth. 31, 876-884.

Nader M.R., Abi Salloum B., Karam N. (2008) Environment and sustainable development indicators in Lebanon: a practical municipal level approach, Ecol. Indic. 8, 771-777.

Nijkamp P., Vreeker R. (2000) Sustainability assessment of development scenarios: methodology and application to Thailand, Ecol. Econ. $33,7-27$.

Noemdoe S., Jonker L., Swatuk L.A. (2006) Perceptions of water scarcity: the case of Genadendal and outstations, Phys. Chem. Earth. 31, 771-778.

Ohlsson L. (2000) Water conflicts and social resource scarcity, Phys. Chem. Earth. 25, 213-220.

Pannell D.J., Glenn N.A. (2000) A framework for the economic evaluation and selection of sustainability indicators in agriculture, Ecol. Econ. 33, 135-149.

Rasul G., Thapa G. B. (2004) Sustainability of ecological and conventional agricultural systems in Bangladesh: an assessment based on environmental, economic and social perspectives, Agric. Syst. 79, $327-351$.

Rezaei-Moghaddam K., Karami E., Gibson J. (2005) Conceptualizing sustainable agriculture: Iran as an illustrative case, J. Sustain. Agr. $27,25-56$.

Rezvani M.R. (2005) An Introduction to rural development planning at Iran, Ghoomes Publications Ltd., Tehran, Iran (in Farsi).

Rigby D., Woodhouse Ph., Young T., Burton M. (2001) Constructing a farm level indicator of sustainable agricultural practice, Ecol. Econ. 39, 463-478.

Rijsberman F.R. (2006) Water scarcity: Fact or fiction? Agric. Water Manage. 80, 5-22.

Rockström J., Folke C., Gordon L., Hatibu N., Jewitt G., Penning de Vries F., Rwehumbiza F., Sally H., Savenije H., Schulze R. (2004) A watershed approach to upgrade rainfed agriculture in water scarce regions through Water System Innovations: an integrated research initiative on water for food and rural livelihoods in balance with ecosystem functions, Phys. Chem. Earth. 29, 1109-1118.
Safinejad J. (1990) Buneh (traditional cultivation systems in Iran), Amir Kabir Publications Ltd., Tehran, Iran (in Farsi).

Safley M. (1998) How traditional agriculture is approaching sustainability? Biomass Bioenergy. 14, 329-332.

Sfandyari O. (2001) Economic-social structure of societies related to Qanats, in: Qanat, Proc. National Conference, Yazd, Iran, pp. 163174 (in Farsi).

Soltani Gh.R. (2009) Optimum use of agricultural water and its role to cope with drought: possibilities and limitations, Drought Problems and Copping Strategies, Proc. National Conference, 23-24 May 2009, Shiraz University, Agricultural College, Shiraz, Iran (in Farsi).

Stephen S.J. (2004) Sustainable agriculture: ecological indicators, Encyclopedia of Plant and Crop Science, Department of Crop and Soil Science, Washington State University, Pullman, Washington, USA (Abstract).

Sullivan C. (2002) Calculating a water poverty index, World Dev. 30, 1195-1211.

Sullivan C., Meigh J. (2003) Considering the water poverty index in the context of poverty alleviation, Water Policy 5, 513-528.

Sullivan C., Meigh J.R., Giacomello A.M., Fediw T., Lawrence P., Samad M., Mlote S., Hutton C., Allan J.A., Schulze R.E., Dlamini D.J.M., Cosgrove W., Delli Priscoli J., Gleick P., Smout I., Cobbing J., Calow R., Hunt C., Hussain A., Acreman M.C., King J., Malomo S., Tate E.L., O'Regan D., Milner S., Steyl I. (2003) The water poverty index: development and application at the community scale, Nat. Resour. Forum 27, 189-199.

Sullivan C., Meigh J., Lawrence P. (2006a) Application of the water poverty index at different scales: a cautionary tale, Water Int. 31 , 412-426.

Sullivan C., Vörösmarty J., Craswell Ch., Bunn E., Cline S., Heidecke S., Storeygard C., Proussevitch A., Douglas A., Bossio E., Günther D., Giacomello D., O'Regan A.M., Meigh J. (2006b) Mapping the links between water, poverty and food security, in: Proc. Workshop "Water Indicators", Centre for Ecology and Hydrology, Wallingford, UK, 16-19 May 2005, GWSP Issues in GWS Research, No. 1. GWSP IPO, Bonn.

Thomas R.J. (2008) Opportunities to reduce the vulnerability of dryland farmers in Central and West Asia and North Africa to climate change, Agric. Ecosyst. Environ. 126, 36-45.

van Cauwenbergh N., Biala K., Bielders C., Brouckaert V., Franchois L., Garcia Cidad V., Hermy M., Mathijs E., Muys B., Reijnders J., Sauvenier X., Valckx J., Vanclooster M., Van der Veken B., Wauters E., Peeters A. (2007) SAFE-A hierarchical framework for assessing the sustainability of agricultural systems, Agric. Ecosyst. Environ. $120,229-242$

Wilson C., Tisdell C. (2001) Why farmers continue to use pesticides despite environmental, health and sustainability costs, Ecol. Econ. 39, $449-462$.

Wulff H.E. (1968) The qanats of Iran, Sci. Am. 94-105.

Wutich A., Ragsdale K. (2008) Water insecurity and emotional distress: coping with supply, access, and seasonal variability of water in a Bolivian squatter settlement, Soc. Sci. Med. 67, 2116-2125.

Yadghar A. (2003) Trend of changes and challenges of rural development in Iran, Geogr. Res. 28, 71-90 (in Farsi).

Yokwe S. (2009) Water productivity in smallholder irrigation schemes in South Africa, Agric. Water Manage. 96, 1223-1228.

Zollinger B., Krannich R.S. (2002) Factors influencing farmers' expectations to sell agricultural land for non-agricultural uses, Rural Sociol. $67,442-463$. 